DOI 10.22363/2312-8631-2019-16-2-162-172

UDK $378+517.9$

\title{
Interdisciplinary scientific communication in the content of teaching applied mathematics
}

\author{
Viktor S. Kornilov \\ Moscow City University \\ 29 Sheremetyevskaya St., Moscow, 127521, Russian Federation
}

Problem and goal. Today, graduates studying in the physical and mathematical areas of training in the profile of applied mathematics have high requirements [23;24]. Such graduates should have not only fundamental knowledge in the disciplines of applied mathematics, have a scientific outlook, skills and research of applied tasks with the help of mathematical modeling, but also strive to implement applied research through environmental technologies. The achievement of such goals in teaching students applied mathematics requires the use of various pedagogical and information technologies in the educational process, the development of learning content, new forms and methods of training, the involvement of specialists in applied mathematics in teaching.

Methodology. In the process of training specialists in applied mathematics, implemented the idea of developing their mathematical creativity, strengthening the motivation for the formation of deep theoretical and practical knowledge in the disciplines of applied mathematics and the foundations of humanitarian culture. The implementation of these important ideas is carried out on the basis of extensive use of interdisciplinary scientific relations in the conditions of humanitarization of university mathematical education. The formation of students' fundamental knowledge of applied mathematics, the foundations of humanitarian culture is achieved by developing the content of such training on the basis of modern scientific achievements of applied mathematics, the implementation of scientific and educational, scientific and educational and humanitarian potential of teaching applied mathematics.

Results. The obtained fundamental knowledge in applied mathematics, formed scientific worldview and humanitarian culture will allow graduates in their future professional activities to show a humane attitude to nature and the world, to apply environmental technologies in the implementation of applied research. In addition, with such a wealth of knowledge, graduates are able to be worthy members of the modern information society with a humanitarian culture.

Conclusion. In the process of teaching applied mathematics, using innovative pedagogical technologies, it is advisable for students not only to give fundamental scientific knowledge, but also to instill the foundations of humanitarian culture.

Key words: teaching applied mathematics; fundamental scientific knowledge in applied mathematics; interdisciplinary scientific relations; student

Problem statement. Scientific achievements of applied mathematics are widely used in many areas of human activity, such as space exploration, airspace, earth environment, the bowels of the oceans; energy, industrial production, economy, agriculture and other spheres of human activity. Fundamental results in the creation of applied mathematics was made by such scientists as G. Galilei, J.L. D’Alembert, N.E. Zhukovsky, A.N. Krylov, D.K. Maxwell, I. Newton, M.V. Ostrogradsky, S.D. Poisson, V.A. Steklov, D.G. Stokes, 
J.B.J. Fourier, S.A. Chaplygin, L. Euler et al. S.N. Bernstein, O.M. Belotserkovsky, E.P. Velikhov, V. Valkovic, N.M. Gunter, M.V. Keldysh, A.N. Kolmogorov, S.P. Korolev, M.A. Lavrent'ev, A.M. Lyapunov, O.E.H. Law, G.I. Marchuk, A.A. Samarskii, S.L. Sobolev. A.N. Tikhonov, E. Schrödinger and other scientists formed modern applied mathematics (see, for example, $[1-4 ; 6-11 ; 19 ; 21 ; 22 ; 25-32]$ ).

A.A. Petrov notes that "Applied mathematics has given excellent tools of knowledge of nature. The study of planetary motion ended with the formulation of general principles of classical mechanics. The concept of momentum, energy, conservation principles provided a heuristic basis for studies of molecular motion and heat. Studies of electrical and magnetic phenomena, which ended with Maxwell's equations, led to the general principles of the theory of relativity. Schrödinger equation forced to reconsider the idea of determinism in nature. The study of nonlinear parabolic equations revealed the general principles of synergetics. Applied mathematics gave not only the tools of knowledge, but also the transformation of the world. The study of the stability of the watt regulator opened the modern control theory. A large section of it was the theory of motion stability developed by A.M. Lyapunov. The optimal control theory of L.S. Pontryagin put on the scientific foundation of the construction of technical objects" [25. Pp. 5-6].

Yu.N. Pavlovsky assigns the most important role of applied mathematics in the development of modern society, noting that "...mathematical modeling will be interpreted as a technology used to predict the development of real phenomena, processes, systems or to predict their properties. This technology (it can be considered as a part of information technology, as it allows to extract new information from the one that is already available) is built into the process of production of material goods and in the process of their consumption so that neither one nor the other in the modern form can exist without this technology, just as they can not exist without modern technologies in the field of energy, transport, etc. ..." [25. Pp. 75-76].

Let's pay attention to what needs of society were satisfied by applied mathematics for the last hundred years. G.G. Malinetsky integrates embedded in the practice of applied research in the most important task. As the first super-task, which was solved in the XX century, he calls the creation of weapons systems and means of protection and notes that the creation of new weapons contributed to the rapid development of natural science. According to him, "...more than half of the fundamental research in developed countries in the past century was initiated by the needs of military-industrial complexes. However, with the creation of strategic weapons systems, these areas of work have come to a natural limit - a number of countries have been able to cause unacceptable damage to all conceivable enemies thousands of times in a variety of ways. The relevant work ceased to be an incentive for fundamental research, and reached the engineering, technical level. Apparently, the creation of a new shield and sword will not be a super-task in the beginning century..." [25. P. 143]. As another super-task of G.G. Malinetsky highlights the task that was solved in connection with the creation of new technologies aimed at expanded reproduction, the creation of new goods and services. At the same time he says: "...we can not agree with the authors of the famous book Factor four - if in the XX century industry sought to produce more and more diverse, in the XXI century it will produce cheaper and more economical [9]. Therefore, the production of goods will not be a supertask...” [25. Pp. 143-144]. 
Speaking about the prospects for the development of applied mathematics, G.G. Malinetsky believes that in the new century there will be super-tasks that will stimulate the development of new applied research and outlines three such interdisciplinary super-tasksas:

- "...the first super-task, risk management and security of complex systems can be singled out. One of the main functions of science in the near future, apparently, will be the prediction and prevention of disasters, catastrophes and other hazards in the natural, man-made social spheres...” [25. P. 144];

- "...the second super-task is now often called neuroscience. One of the most important predicted achievements of science of the XXI century, according to many experts, will be the opening of the psychological code. That is, the elucidation of encoding, transmission, algorithms of information processing in the nervous system, biological analysis of consciousness. Modern information technologies, the use of a number of types of tomographs and algorithms for reconstruction of volumetric structures allow us to see the thought - to record the activity of different parts of the brain in real time..." [25. P. 145];

- "...the third super-task is sometimes called an alternative or theoretical history. This task is increasingly associated with the analysis of strategic risks - events, technologies, solutions that can significantly narrow the corridor of capabilities of countries, regions or civilizations, lead them to a crisis or catastrophe...” [25. P. 147].

If from that point of view to look at applied mathematics, it is one of such phenomena of culture, which currently affects many areas of human activity in our society.

Methods of research. Professional orientation of teaching applied mathematics bachelors and masters in the physical and mathematical areas of training determines the list of basic mathematical disciplines included in the relevant educational programs for which such training is conducted. Among such basic mathematical disciplines of applied mathematics are mathematical analysis, functional analysis, complex analysis, analytical geometry, algebra, optimization methods, probability theory and mathematical statistics, discrete mathematics and mathematical logic, numerical methods, integral equations, ordinary differential equations, partial differential equations and other mathematical disciplines of applied mathematics.

Fundamental knowledge of the above basic mathematical disciplines of applied mathematics allows bachelors and undergraduates to master a variety of methods of mathematical physics, which can be used to study a variety of mathematical models.

During the years of existence of faculties and departments of applied mathematics in Russia formed the leading scientific schools in the fundamental areas of applied mathematics, such as mathematical physics and spectral theory of differential equations, inverse and ill-posed problems, computational methods and mathematical modeling, nonlinear dynamic systems and control processes, synergetics, game theory and operations research, optimal control and system analysis, mathematical cybernetics and mathematical logic, probability theory and mathematical statistics, theoretical and applied programming and other scientific schools.

Mathematical modeling as a scientific method of studying the world in modern world science is one of the central places. This circumstance is explained by the fact that 
mathematical models have important properties from the scientific point of view, including scientific and cognitive potential and universality. And the presence of modern computer technology allows mobile research and visualization of solutions to a wide variety of mathematical models. It is not a coincidence that mathematical modeling is included in the content of many disciplines of applied mathematics.

Mathematical modeling is widely used in modern applied research (see, for example, $[1-4 ; 6 ; 7 ; 10 ; 13 ; 16-19 ; 21 ; 25-32])$. The great need for the use of mathematical models in applied research is explained by the possibility of effective research of objects and processes of different nature, difficult or inaccessible to man, determining their location, shape, structure of inclusions, etc., revealing their cause-and-effect relationships. All this, in many respects, became possible thanks to the use of modern information and telecommunication technologies.

Results and discussion. In the process of teaching applied mathematics, students acquire the skills and abilities to form new scientific knowledge about the world, about the physical processes and phenomena occurring in it and their cause-and-effect relationships.

For example. In the study of mathematical models of electrodynamics, students gain scientific knowledge about the processing and interpretation of the results of measuring electromagnetic radiation generated by various objects, the sources of electromagnetic fields, the forms of bodies on which the field is scattered, the inhomogeneities of the earth's environment, the synthesis of the electromagnetic field, etc. (see, for example, $[16-19 ; 21 ; 31])$. In the study of mathematical models of atmospheric optics, students gain scientific knowledge about the physical state of the atmosphere, the concentration of absorbing and scattering substances, the size and shape of aerosol particles, their composition and structure, the parameters of the fine structure of the spectrum, the radiation intensity, etc. (see, for example, [28]). In the study of mathematical models of photo processing students gain scientific knowledge in the field of pattern recognition, reconstruction of blurred and defocused images, tomography (see, for example, [22]).

When finding solutions to mathematical models, students also acquire new scientific knowledge in subject areas that are not included in the content of traditional mathematical disciplines of applied and computational mathematics, and can be acquired only in the process of teaching special courses. For instance, in the study of mathematical models of spectral problems, students acquire scientific knowledge in the field of spectral analysis, which consists in determining the operators of some of their spectral characteristics. Students realize that such mathematical models play an important role in applications of physics, quantum mechanics, geophysics, meteorology, radioelectronics, elasticity theory and other applications. In the process of solving such mathematical models, students master the method of spectral maps, the method of reference models, the method of transformation operator and other mathematical methods (see, for example, [32]).

Let us give more examples. In the study of mathematical models using approximate methods, students acquire deep scientific knowledge in the field of computational mathematics. Among such scientific knowledge - the theory of difference schemes, finite-difference methods, method of run, iterative methods, Tikhonov regularization method, Newton - Kantorovich method, gradient methods, discrete analogue of the 
Volterra operator equation with bounded Lipschitz continuous core. Methods of error estimation of approximate solutions of mathematical models to exact solutions and other methods are mastered. At the same time, students widely use computer technology to implement computational algorithms for finding approximate solutions of mathematical models that demonstrate to students their efficiency and mobility in the study of applied problems.

Modern applied mathematics is characterized by such features as analysis of mathematical models, increasing the role of general mathematical structures, the spread of ideas of optimality, algorithmization, humanitarization and other features. In this connection, the implementation of interdisciplinary scientific relations in the process of teaching applied mathematics, due to the need to integrate natural science and humanities, which allows students to form a system of fundamental knowledge in the field of applied mathematics, to comprehend the cognitive and humanitarian potential of mathematical models, to understand the epistemological processes in applied mathematics, to identify the basic concepts of scientific disciplines, such as computer science, philosophy and other scientific disciplines.

For clarity, we give examples. When teaching applied mathematics, students are informed that mathematical models are universal and are able to describe processes of different nature. And this universalism increases the cognitive potential of such mathematical models. Students are explained that mathematical models are universal when they are syntactic in nature, when semantics, meaningful knowledge and the meaning of the simulated process remain outside of this mathematical model. In this case, it is difficult to conclude what specific process is described by this model.

Students realize that the methods of research of mathematical models, their cognitive potential can be used in the study of various nature of applied problems. In the process of such training interdisciplinary connections of applied mathematics and informatics are revealed; students develop mathematical creativity, scientific outlook, fundamental knowledge in the field of applied mathematics; system of scientific knowledge about the basic concepts of computer science as a scientific discipline, such as information, modeling, formalization, algorithmization, computational experiment, syntax, semantics, computer graphics, information technology and other basic concepts of computer science. The subsequent analysis of the applied and humanitarian aspects of the obtained results of the inverse problem allows students to draw appropriate logical conclusions about the studied process and, ultimately, to obtain new information, to study its properties and to comprehend its value (see, for example, $[5 ; 12-17 ; 20]$ ).

Considering in the classroom mathematical problems for the system of Maxwell's equations, to the understanding of students, teachers are informed that the reasons for such problems are, in particular, the coefficients of dielectric and magnetic permeability, electrical conductivity of the earth's environment, and the consequences are additional information about the solution of the relevant direct problems. Having such knowledge, exploring such applied problems by mathematical methods, students form scientific knowledge about the heterogeneous structure of the earth's environment, its deep properties. Such scientific knowledge is widely used in seismology, geoelectrics, gravimetry, electrodynamics and other scientific fields; in the search for minerals, in industry. 
Implementation of interdisciplinary scientific relations in teaching applied mathematics, allows students to form a deep subject theoretical knowledge, acquire the skills and abilities of using mathematical methods for the study of applied problems. Students are able to carry out applied and humanitarian analysis of the solutions of mathematical problems, to develop a scientific outlook and mathematical creativity, to replenish their scientific knowledge in applied and computational mathematics, as well as in the field of such fundamental concepts of philosophy as cause and effect.

In the process of teaching applied mathematics attention is paid to the philosophical aspects of the phenomenon of acquired information. Realizing the philosophical aspects of the identified in solving applied problems of cause-and-effect relations and the phenomenon of new information, students understand that applied mathematics is related to such methods of human knowledge as theory, experiment and philosophy. Philosophical understanding of cause-and-effect relationships and the concept of information helps students to master the methodological possibilities in understanding the surrounding reality; it helps to understand that the information acquired as a result of solving the inverse problem is also connected with fundamental philosophical questions of natural science.

Conclusion. Analysis of applied, humanitarian and philosophical aspects of the obtained results of solving applied problems allows students to form appropriate logical conclusions about the studied process, to comprehend the scientific and humanitarian value of the new information. The integration of interdisciplinary scientific relations in the process of teaching applied mathematics allows to identify the humanitarian, scientific and educational potential of such training, to identify the contribution of teaching applied mathematics in humanitarization and fundamentalization of mathematical education.

(C) Kornilov V.S., 2019

This work is licensed under a Creative Commons Attribution 4.0 International License

\section{References}

[1] Aramanovich I.G., Levin V.I. Uravneniya matematicheskoj fiziki [Equations of mathematical physics]. Moscow: Nauka Publ., 1969. 286 p.

[2] Arnold V. I. "Zhestkie i myagkie" matematicheskie modeli [ "Hard and soft" mathematical models]. Moscow: MCNMO Publ., 2004. 32 p.

[3] Arsenin V.Ya. Metody matematicheskoj fiziki i special'nye funkcii [Methods of mathematical physics and special functions]. Moscow: Nauka Publ., 1984. 383 p.

[4] Ashihmin V.N. Vvedenie v matematicheskoe modelirovanie: uchebnoe posobie [Introduction to mathematical modeling: textbook]. Moscow: Logos Publ., 2015. 440 p.

[5] Bidaibekov E.S., Kornilov V.S., Kamalova G.B. Obuchenie budushhih uchitelej matematiki i informatiki obratnym zadacham dlja differencial'nyh uravnenij [The training of future teachers of mathematics and informatics inverse problems for differential equations]. Vestnik Moskovskogo gorodskogo pedagogicheskogo universiteta. Seriya: Informatika i informatizacija obrazovanija [Bulletin of the Moscow City Pedagogical University. Series: Informatics and Informatization of Education]. 2014. No. 3(29). Pp. 57-69.

[6] Blekhman I.M., Myshkis A.D., Panovko Ya.G. Prikladnaya matematika: predmet, logika, osobennosti podhodov [Applied mathematics: the subject, the logic, the features of the approaches]. Moscow: KomKniga Publ., 2005. 376 p. 
[7] Bolotelov N.V., Brodskij Yu.I., Pavlovskij Yu.N. Slozhnost’. Matematicheskoe modelirovanie. Gumanitarnyj analiz: Issledovanie istoricheskih, voennyh, social'no-ekonomicheskih i politicheskih processov [Complexity. Mathematical modeling. Humanitarian analysis: study of historical, military, socio-economic and political processes]. Moscow: Librokom Publ., 2009. 320 p.

[8] Bordovskij G.A., Kondrat'ev A.S., Chouderi A.D.R. Fizicheskie osnovy matematicheskogo modelirovaniya: uchebnoe posobie [Physical bases of mathematical modeling: textbook]. Moscow: Akademiya Publ., 2005. 316 p.

[9] Vajczekker E., Lovins E., Lovins L. Faktor chetyre [Factor four]. Moscow: Akademiya, 1997. $400 \mathrm{p}$.

[10] Zel'dovich Ya.B., Myshkis A.D. Elementy prikladnoj matematiki [Elements of applied mathematics]. Moscow: Nauka Publ., 1967. 646 p.

[11] Kornilov V.S. Vuzovskaya podgotovka specialistov po prikladnoj matematike - istoriya i sovremennost' [University training of specialists in applied mathematics - history and modernity]. Nauka i shkola [Science and school]. 2006. No. 4. Pp. 10-12.

[12] Kornilov V.S. Laboratornye zanjatija kak forma organizacii obuchenija studentov fraktal'nym mnozhestvam [Laboratory sessions as a form of organization of teaching students fractal sets]. Vestnik Moskovskogo gorodskogo pedagogicheskogo universiteta. Serija: Informatika i informatizacija obrazovanija [Bulletin of the Moscow City Pedagogical University. Informatics and Informatization of Education Series]. 2012. No. 1(23). Pp. 60-63.

[13] Kornilov V.S. Obratnye zadachi v soderzhanii obucheniya prikladnoj matematike [Inverse problems in the content of teaching applied mathematics]. Vestnik Rossijskogo universiteta druzhby narodov. Seriya: Informatizacija obrazovanija [Bulletin of Peoples' Friendship University of Russia. Series: Informatization in Education]. 2014. No. 2. Pp. 109-118.

[14] Kornilov V.S. Obuchenie studentov obratnym zadacham matematicheskoj fiziki kak factor formirovanija fundamental'nyh znanij po integral'nym uravnenijam [Training of students in the inverse problems of mathematical physics as factor of formation of fundamental knowledge of the integrated equations]. Bjulleten' laboratorii matematicheskogo, estestvennonauchnogo obrazovanija i informatizacii: recenziruemyj sbornik nauchnyh trudov [Bulletin of laboratory of mathematical, natural-science education and informatization: the reviewed collection of scientific works]. 2015. Vol. VI. Pp. 251-257.

[15] Kornilov V.S. Realizacija nauchno-obrazovatel'nogo potenciala obuchenija studentov vuzov obratnym zadacham dlja differencial'nyh uravnenij [Realization of scientific and educational potential of training of students of higher education institutions in the inverse problems for the differential equations]. Kazanskij pedagogicheskij zhurnal [Kazan pedagogical journal]. 2016. No. 6. Pp. 55-59.

[16] Kornilov V.S. Teorija i metodika obuchenija obratnym zadacham dlja differencial'nyh uravnenij: monografija [Theory and technique of training to the inverse problems for differential equations: monography]. Moscow: OntoPrint Publ., 2017. 500 p.

[17] Kornilov V.S. Formirovanie fundamental'nyh znanij po matematicheskomu modelirovaniyu pri obuchenii obratnym zadacham dlya differencial'nyh uravnenij [Formation of the fundamental knowledge on mathematical modeling in teaching inverse problems for differential equations]. Vestnik Moskovskogo gorodskogo pedagogicheskogo universiteta. Seriya: Informatika i informatizacija obrazovanija [Bulletin of the Moscow City Pedagogical University. Series: Informatics and Informatization of Education]. 2017. No. 1(39). Pp. 92-99.

[18] Kornilov V.S., Kartashova L.I. Praktikum po prikladnoj matematike: uchebno-metodicheskoe posobie [Practical work on applied mathematics: educational-methodical manual]. Voronezh: Nauchnaya kniga Publ., 2013. 100 p.

[19] Lavrent'ev M.M., Romanov V.G., Shishatskij S.P. Nekorrektnye zadachi matematicheskoj fiziki i analiza [Ill-Posed problems of mathematical physics and analysis]. Moscow: Nauka Publ., 1980. $286 \mathrm{p}$.

[20] Levchenko I.V., Kornilov V.S., Belikov V.V. Rol' informatiki v podgotovke specialistov po prikladnoj matematike [The role of informatics in the training of specialists in applied mathematics]. Vestnik Moskovskogo gorodskogo pedagogicheskogo universiteta. Seriya: Informatika i informatizacija 
obrazovanija [Bulletin of the Moscow City Pedagogical University. Series: Informatics and Informatization of Education]. 2009. No. 2(18). Pp. 108-112.

[21] Martinson L.K., Malov Yu.I. Differencial'nye uravneniya matematicheskoj fiziki [Differential equations of mathematical physics]. Moscow: MGTU imeni N.E. Baumana Publ., 1996. 367 p.

[22] Tihonov A.N., Goncharskii A.V. (eds). Nekorrektnye zadachi estestvoznaniya: sbornik nauchnyh trudov [Ill-posed problems of natural science: collection of scientific works]. Moscow: Moskovskii universitet Publ., 1987. 303 p.

[23] Portal Federal'nyh gosudarstvennyh obrazovatel'nyh standartov vysshego obrazovaniya po napravleniyam bakalavriata [Portal of Federal state educational standards of higher education in the areas of undergraduate]. http://fgosvo.ru/fgosvo/92/91/4/28 (accessed: 15.01.2019).

[24] Portal Federal'nyh gosudarstvennyh obrazovatel'nyh standartov vysshego obrazovaniya po napravleniyam magistratury [Portal of Federal state educational standards of higher education in the areas of magistracy]. http://fgosvo.ru/fgosvo/93/91/5/30 (accessed: 15.01.2019).

[25] Petrov A.A. (ed.). Sovremennye problemy prikladnoj matematiki: sbornik nauchno-populyarnyh statej. T. 1 [Modern problems of applied mathematics: collection of scientific-popular articles. Vol. 1]. Moscow: MZ Press Publ., 2005. 231 p.

[26] Tarasevich Yu.Yu. Matematicheskoe i komp’yuternoe modelirovanie. Vvodnyj kurs: uchebnoe posobie [Mathematical and computer modeling. Introductory course: textbook]. Moscow: Editorial URSS Publ., 2004. 152 p.

[27] Izbrannye trudy A.N. Tihonova [Selected works of A.N. Tikhonov]. Moscow: MAKS Press Publ., 2001. $485 \mathrm{p}$.

[28] Timofeev Yu.M., Polyakov A.V. Matematicheskie aspekty resheniya obratnyh zadach atmosfernoj optiki: uchebnoe posobie [Mathematical aspects of solving inverse problems of atmospheric optics: textbook]. Saint Petersburg: Sankt-Peterburgskii universitet Publ., 2001. 188 p.

[29] Tihonov A.N., Arsenin V.Ya. Metody resheniya nekorrektnyh zadach [Methods of solving ill-posed problems]. Moscow: Nauka Publ., 1986. 287 p.

[30] Tihonov A.N., Kostomarov D.P. Rasskazy o prikladnoj matematike [Stories about applied mathematics]. Moscow: Nauka Publ., 1979. 206 p.

[31] Tihonov A.N., Samarskij A.A. Uravneniya matematicheskoj fiziki [Equations of mathematical physics]. Moscow: MGU Publ., 1999. 798 p.

[32] Yurko V.A. Vvedenie v teoriyu obratnyh spektral'nyh zadach: uchebnoe posobie [Introduction to the theory of inverse spectral problems: textbook]. Moscow: Fizmatlit Publ., 2007. 384 p.

\section{Article history:}

Received: 15 January 2019

Accepted: 20 February 2019

\section{For citation:}

Kornilov V.S. (2019). Interdisciplinary scientific communication in the content of teaching applied mathematics (Междисциплинарные научные связи в содержании обучения прикладной математике). RUDN Journal of Informatization in Education, 16(2), 162-172. http://dx.doi. org/10.22363/2312-8631-2019-16-2-162-172

\section{Bio note:}

Viktor S. Kornilov, doctor of pedagogical sciences, candidate of physical and mathematical sciences, full professor, deputy head of the department of informatization of education of the Moscow City University. Contact information: e-mail: vs_kornilov@mail.ru 


\title{
Междисциплинарные научные связи в содержании обучения прикладной математике
}

\author{
В.С. Корнилов \\ Московский городской педагогический университет \\ Российская Федерация, 127521, Москва, ул. Шереметьевская, 29
}

Проблема и цель. Сегодня к выпускникам, обучающихся на физико-математических направлениях подготовки по профилю прикладной математики, предъявляются высокие требования [23; 24]. Они должны иметь не только фундаментальные знания по дисциплинам прикладной математики, обладать научным мировоззрением, умениями и навыками исследования прикладных задач при помощи математического моделирования, но и стремиться реализовывать прикладные исследования природоохранными технологиями. Достижение таких целей при обучении студентов прикладной математике требует использования в учебном процессе различных педагогических и информационных технологий, разработки содержания обучения, новых форм и методов обучения, привлечения к преподавательской деятельности специалистов по прикладной математике.

Методология. В процессе подготовки специалистов по прикладной математике реализуются идеи развития их математических творческих способностей, усиление мотивации к формированию глубоких теоретических и практических знаний по дисциплинам прикладной математики и основ гуманитарной культуры. Реализация этих важных идей осуществляется на базе широкого использования междисциплинарных научных связей в условиях гуманитаризации вузовского математического образования. Формирование студентами фундаментальных знаний по прикладной математике и основ гуманитарной культуры достигается разработкой содержания обучения на основе современных научных достижений прикладной математики, реализацией научно-образовательного, научно-познавательного и гуманитарного потенциала обучения прикладной математике.

Результаты. Полученные фундаментальные знания по прикладной математике, сформированное научное мировоззрение и гуманитарная культура позволят выпускникам в своей будущей профессиональной деятельности проявлять гуманное отношение к природе и окружающему миру, применять природоохранные технологии при реализации прикладных исследований. Кроме того, с таким багажом знаний выпускники способны стать достойными членами современного информационного общества с гуманитарной культурой.

Заключение. В процессе обучения прикладной математике, применяя инновационные педагогические технологии, целесообразно не только давать студентам фундаментальные научные знания, но и прививать основы гуманитарной культуры.

Ключевые слова: обучение прикладной математике; фундаментальные научные знания по прикладной математике; междисциплинарные научные связи; студент

\section{Список литературы}

[1] Араманович И.Г., Левин В.И. Уравнения математической физики. М.: Наука, 1969. 286 с.

[2] Арнольд В.И. «Жесткие и мягкие» математические модели. М.: МЦНМО, 2004. 32 с.

[3] Арсенин В.Я. Методы математической физики и специальные функции. М.: Наука, 1984. $383 \mathrm{c}$.

[4] Ашихмин В.Н. Введение в математическое моделирование: учебное пособие. М.: Логос, $2015.440 \mathrm{c}$.

[5] Бидайбеков Е.Ы., Корнилов В.С., Камалова Г.Б. Обучение будущих учителей математики и информатики обратным задачам для дифференциальных уравнений // Вестник Мо- 
сковского городского педагогического университета. Серия: Информатика и информатизация образования. 2014. № 3 (29). С. 57-69.

[6] Блехман И.М., Мышкис А.Д., Пановко Я.Г. Прикладная математика: предмет, логика, особенности подходов. М.: КомКнига, 2005. 376 с.

[7] Болотелов Н.В., Бродский Ю.И., Павловский Ю.Н. Сложность. Математическое моделирование. Гуманитарный анализ: исследование исторических, военных, социально-экономических и политических процессов. М.: Либроком, 2009. 320 с.

[8] Бордовский Г.А., Кондратьев А.С., Чоудери А.Д.Р. Физические основы математического моделирования: учебное пособие. М.: Академия, 2005. 316 с.

[9] Вайизеккер Э., Ловинс Э., Ловинс Л. Фактор четыре. М.: Академия, 1997. 400 с.

[10] Зельдович Я.Б., Мышкис А.Д. Элементы прикладной математики. М.: Наука, 1967. 646 с.

[11] Корнилов В.С. Вузовская подготовка специалистов по прикладной математике - история и современность // Наука и школа. 2006. № 4. С. 10-12.

[12] Корнилов B.C. Лабораторные занятия как форма организации обучения студентов фрактальным множествам // Вестник Московского городского педагогического университета. Серия: Информатика и информатизация образования. 2012. № 1 (23). С. 60-63.

[13] Корнилов B.C. Обратные задачи в содержании обучения прикладной математике // Вестник Российского университета дружбы народов. Серия: Информатизация образования. 2014. № 2. С. 109-118.

[14] Корнилов B.C. Обучение студентов обратным задачам математической физики как фактор формирования фундаментальных знаний по интегральным уравнениям // Бюллетень лаборатории математического, естественнонаучного образования и информатизации: рецензируемый сборник научных трудов. Т. VI. Самара: Самарский филиал МГПУ, 2015. C. $251-257$.

[15] Корнилов В.C. Реализация научно-образовательного потенциала обучения студентов вузов обратным задачам для дифференциальных уравнений // Казанский педагогический журнал. 2016. № 6. С. 55-59.

[16] Корнилов B.C. Теория и методика обучения обратным задачам для дифференциальных уравнений: монография. М.: ОнтоПринт, 2017. 500 с.

[17] Корнилов В.С. Формирование фундаментальных знаний по математическому моделированию при обучении обратным задачам для дифференциальных уравнений // Вестник Московского городского педагогического университета. Серия: Информатика и информатизация образования. 2017. № 1 (39). С. 92-99.

[18] Корнилов В.С., Карташова Л.И. Практикум по прикладной математике: учебно-методическое пособие. Воронеж: Научная книга, 2013. 100 с.

[19] Лаврентьев М.М., Романов В.Г., Шишатский С.П. Некорректные задачи математической физики и анализа. М.: Наука, 1980. 286 с.

[20] Левченко И.В., Корнилов В.С., Беликов В.В. Роль информатики в подготовке специалистов по прикладной математике // Вестник Московского городского педагогического университета. Серия: Информатика и информатизация образования. 2009. № 2 (18). С. $108-$ 112.

[21] Мартинсон Л.К., Малов Ю.И. Дифференциальные уравнения математической физики. М.: МГТУ имени Н.Э. Баумана, 1996. 367 с.

[22] Некорректные задачи естествознания: сборник научных трудов / под ред. А.Н. Тихонова, А.В. Гончарского. М.: Изд-во Московского университета, 1987. 303 с.

[23] Портал Федеральных государственных образовательных стандартов высшего образования по направлениям бакалавриата. URL: http://fgosvo.ru/fgosvo/92/91/4/28 (дата обращения: 15.01.2019).

[24] Портал Федеральных государственных образовательных стандартов высшего образования по направлениям магистратуры. URL: http://fgosvo.ru/fgosvo/93/91/5/30 (дата обращения: 15.01.2019).

[25] Современные проблемы прикладной математики: сборник научно-популярных статей. Вып. 1 / под ред. А.А. Петрова. М.: МЗ Пресс, 2005. 231 с. 
[26] Тарасевич Ю.Ю. Математическое и компьютерное моделирование. Вводный курс: учебное пособие. М.: Едиториал УРСС, 2004. 152 с.

[27] Избранные труды А.Н. Тихонова. М.: МАКС Пресс, 2001. 485 с.

[28] Тимофеев Ю.М., Поляков А.В. Математические аспекты решения обратных задач атмосферной оптики: учебное пособие. СПб.: Изд-во Санкт-Петербургского университета, 2001. $188 \mathrm{c}$.

[29] Тихонов А.Н., Арсенин В.Я. Методы решения некорректных задач. М.: Наука, 1986. 287 с.

[30] Тихонов А.Н., Костомаров Д.П. Рассказы о прикладной математике. М.: Наука, 1979. 206 с.

[31] Тихонов А.Н., Самарский А.А. Уравнения математической физики. М.: Изд-во МГУ, 1999. $798 \mathrm{c}$.

[32] Юрко B.A. Введение в теорию обратных спектральных задач: учебное пособие. М.: Физматлит, 2007. $384 \mathrm{c}$.

\section{История статьи:}

Дата поступления в редакцию: 15 января 2019

Дата принятия к печати: 20 февраля 2019

\section{Для цитирования:}

Kornilov V.S. Interdisciplinary scientific communication in the content of teaching applied mathematics (Междисциплинарные научные связи в содержании обучения прикладной математике) // Вестник Российского университета дружбы народов. Серия: Информатизация образования. 2019. Т. 16. № 2. С. 162-172. http://dx.doi.org/10.22363/2312-86312019-16-2-162-172

\section{Сведения об авторе:}

Корнилов Виктор Семенович, доктор педагогических наук, кандидат физико-математических наук, профессор, заместитель заведующего кафедрой информатизации образования Московского городского педагогического университета. Контактная информация: e-mail: vs_kornilov@mail.ru 